\title{
Christianity and Indigenisation in Africa
}

\author{
M. A. Masoga and A. Nicolaides
}

\section{ABSTRACT}

In a quest for greater coherence between parochial identities, culture and Christianity, there exists an African consciousness which seeks to indigenise and decolonise Christianity. Africans are profoundly religious people who view their faith as part of their way of life, as strengthening their cultures and providing a moral compass for daily living. In efforts to transform society, the Christian religion has played a significant role in the path to African development. Christianity in Africa dates to the very inception of the church. Africans consequently played a crucial role in establishing the doctrines and theology of the early church. While African Traditional religion (ATR) is paramount, it is the purpose of this article to suggest that the Christian faith has and continuous to play a significant role on the African continent in its development. While there are many indigenous African beliefs, these have been to a large extent supported by Christianity in a quest to systematize novel knowledge and promote peace and tolerance across the continent. Many Africans have sought facets of Christianity that are similar to their religious and personal practices and continue to do so. Thus, while there exist numerous similarities and also differences between Christianity and ATR, it is imperative to preserve old-style regional distinctiveness and Christianity as the unifying rudiments in nation building endeavours and in efforts to spread the gospel of Jesus Christ. Africans can and should come to comprehend the Triune Godhead as being consistent with their own spiritual consciousness and existential veracities. Indigenisation of Christianity requires enculturation and essentially an understanding that it is indeed ecumenical and also embraces diversity and fundamentally requires viewing Holy Scriptures and the truths they propound as being applicable to any context and cultural milieu across the ages. Christians after all espouse a faith in the Ekklesia or body of Christ for all its people who are the Laos of God.

Keywords: Africa, Christianity, indigenisation, socio-cultural development, traditional faith.
Published Online: August 08, 2021

ISSN: $2736-5514$

DOI : $10.24018 /$ theology.2021.1.4.33

\section{A. Masoga}

Dean Faculty of Arts University of Zululand, South Africa.

(e-mail: MasogaM@unizulu.ac.za)

\section{A. Nicolaides *}

HoD Department of Philosophy and Applied Ethics, Faculty of Arts, University of Zululand, South Africa. (e-mail: nicolaidesa@ unizulu.ac.za)

*Corresponding Author

\section{INTRODUCTION}

Africa is currently the most vibrant global centre of Christianity when it comes to new adherents. The continent has a substantial portion of the world's 2.2 billion people who espouse Christianity. The continent is home to a wide range of denominations:

...30 percent of the world's evangelicals, 20 percent of the world's Pentecostals and charismatics, and about 15 percent of the world's Roman Catholics. In addition, Africa has significant Orthodox groups such as the Ethiopian and Eritrean Orthodox Tewahedo Churches and the Coptic Orthodox Church of Alexandria [1].

Christianity is currently the religion of choice of most of the population of Southern African, Southeast African, and Central African states as well as some parts of the Horn of Africa and areas in West Africa. The Coptic Christians make up a significant minority in Egypt. In 2020, Christians accounted for $49 \%$ of the continent's populace, with Muslims making up $42 \%$ [2]. Africa has gone from having a majority of followers of indigenous, traditional religions, to being predominantly a continent of Christians and Muslims [3]. From about 2013 onwards, traditional African religions have been acknowledged as the majority religion in only Togo and within most Christian communities in Africa, there is a momentous and continued amalgamation or attempted amalgamation of different religions, and especially with a wide range of traditional African religious beliefs and practices [2].

An African conception of religion based on indigenous cultural heritage and insight can certainly contribute to the universal phenomenon of what religion is and does to humans and their souls. It adds value to religion per se as it rouses people to deeper spirituality and insightfulness of the experience of the divine-human connection based on ATR which includes a spirituality which has existed for many centuries [4]. Religion is essentially an explicit set of organised beliefs and practices which are usually shared by a community or group, while spirituality is more of an individual practice and involves a believer having a sense of amity and purpose in life. In the context of this article the term religion is used as referring to beliefs which seek to build one's character and shape one's beliefs, attitude, and actions. It does so by stating the importance of adhering to rules which 
unite people who share a particular religion.

Spirituality on the other hand, concentrates more on each person's individual soul. Spiritual beliefs then include the relationship to a superior being and are associated with an existential perspective on both life and death, and the nature of reality. Religious beliefs which build spirituality include practices or rituals such as prayer, meditation, and engagement with other members in one's religious community. Religion then is believing, while spirituality is being. The two concepts overlap as each person's individual experience influences how they think, feel, and act. Thus, in this article the term religion incorporates both.

Having said as much, Canaris [5] asserts: "In 1900, there were less than 10 million Christians on the continent, many of whom were non-native missionaries. A century later in the year 2000, there were 350 million. By 2025, that number is expected to nearly double, to somewhere between 630 and 700 million believers".

Mbiti [6] has contended that since ATR envelops one entirely, the conversion of new adherents to Christianity should embrace their language, thinking, qualms, social relationships, attitudes, and metaphysical nature if they are to be successfully transformed for the betterment of their societies. Consequently, the inculturation of Christianity is required in Africa [7]. The African continent has offered a propitious milieu for the spread of Christianity since Mark the Evangelist became ordained as the first bishop of the Orthodox Church of Alexandria in Egypt in about the year $43 \mathrm{CE}$. In the ensuing 200 years, Christianity gradually spread to the native Egyptian-speaking population. Under Patriarch Dionysius (247-264 CE), Christianity flourished throughout Egypt, and more especially around the Nile Valley and Fayyum [8]. Thus, by approximately $320 \mathrm{CE}$, the Bishop of Alexandria presided over a probable 90 or more bishoprics in what are today Egypt and Libya, and the chief concentration was in the Nile Delta region.

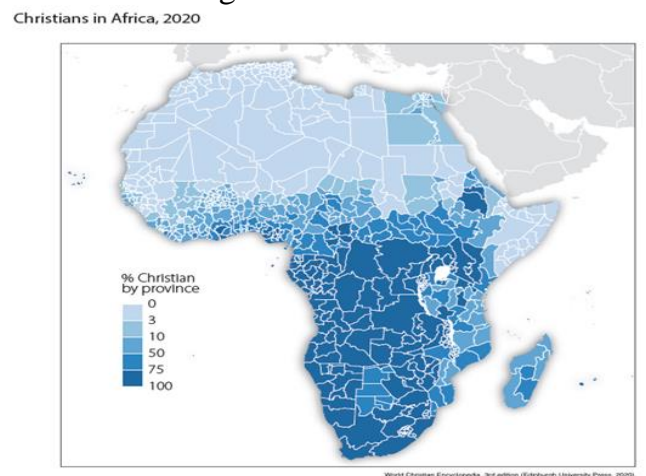

Fig. 1. Christians in Africa 2020 (World Christian Encyclopedia).

\section{THE IMPACT OF AFRICA ON EARLY CHRISTIANITY}

Neff [9] reminds us: "Many of the shapers of Christian orthodoxy were African". In the third century CE there were rapid advances in Christianity in North Africa, partially due to the conversion of numerous Jews to the faith. Where there was oppression and maltreatment of people this also strengthened the faith of Christian adherents who were determined to preserve their faith and many Christians gathered to pray together, to instruct, and also to baptize new believers [10]-[12]. Thus, this period of the third century CE, witnessed the rise of many of the Early Church Fathers who were of North African origin and numerous Councils held in North Africa aided the early Church to affirm and accept which books to include in Holy Scripture. Alexandria was the most important environment for the development of the theology of Christianity and from there it spread to the rest of the Roman Empire and the known parts of Africa, Asia, and Europe [13].

The development of Christianity in Alexandria was due to its Didaskaleion which was a top-notch educational institution which provided theological instruction which put Christian theology in good stead [14], [15]. Two prominent heads of the school were Clement and Origen [13]. Pearson [16] reminds of Christian activity in Alexandria and asserts that the initial preaching of the gospel of Jesus Christ in Alexandria was based in the Jewish community which lived in the city. The early Christian Church grew rapidly, and Alexandria was arguably more important than even Rome and Antioch [17]. If we also include Carthage (Africa Proconsularis) where Tertullian and Cyprian lived, and Cyrene (Cyrenaica), Africa developed into a stronghold for Christianity [18].

We can for example briefly mention only six out of many people of African descent who had a profound impact on Christianity.

Cyprian (210 - 258 CE) who was a Bishop of Carthage (in modern day Tunisia), was a distinguished early Christian writer. He wrote many works in Latin which have survived and were edited in volumes 3 and 4 of the Patrologia Latina [19]. He wrote valuable works relating to pastoral ministry issues and was not a speculative theologian [20]. The Conciliar method was also his work. Conciliarism was a reform movement in the $14^{\text {th }}-16^{\text {th }}$ centuries CE Catholic Church, which maintained that supreme authority in the Church was inherent in Ecumenical councils, apart from, or often even against, the pope [18], [21]. Cyprian developed a constitutional theory of the Church in his treatise De unitate ecclesiae and was of the opinion that the "episcopate" was a single, divinely appointed, governing office shared by many bishops. Furthermore, each of them had complete authority of the office in their own milieu. He offered the example of Christ's Apostles who were the first bishops, and their full authority had continued in the duly elected and consecrated bishops who became their successors. This when one acts apart from the bishop, one places oneself outside the Church and then loses the hope of salvation [22].

Augustine of Hippo (354 - 430 CE), was another African of Christian of theological repute as well as a philosopher. He was born in what is now Algeria and was to all accounts one of the most influential scholars and philosophers of this time as he infused Christian doctrine with Neoplatonism. He held the belief that the free will of man could decide his own destiny. His notions of interior psychological analysis were novel [18].

\section{Augustine synthesised:}

...the Neoplatonic ideals of truth and beauty with the passionate Christian belief in a loving God. This synthesis of reason and mysticism resulted in a moral structure that has had the practical effect of bringing 
order to countless lives over the centuries largely because it makes self-transcendence so worthwhile... In essence, Augustine's solution to both the ontological and metaphysical problems addressed in his arguments for the subordination of human will to God's caring, omnipotent will continues to inspire transcendence because of the tremendous aesthetic appeal of a cosmology that meets basic human needs for both compassion and order [23].

His influence resonates in the work of many who succeeded him. His numerous writings influenced the development of Western philosophy and Western Christianity. Consequently, he is viewed as one of the most significant Church Fathers of the Latin Church in the Patristic Period [24], [25]. Some of his countless central works include two doctrinal masterpieces, the De trinitate and the De civitate Dei which starts with an apologetic purpose, and later on takes on the form of a history of the City of God from its beginnings. He also wrote the marvellous works On Christian Doctrine, and Confessions. Augustine was one of the first Christian ancient Latin authors with a very distinct idea of theological anthropology. He viewed the human being as comprising a perfect unity of soul and body [26].

Athanasius I of Alexandria (296-373 CE), was a celebrated Egyptian leader who was bishop of Alexandria and an astute Christian theologian. He became a Church Father and was the foremost protector of Trinitarianism against Arianism which took a position that the Son of God, Jesus of Nazareth, is of a separate substance from the Father [27]. Gregory of Nazianzus referred to Athanasius as the "Pillar of the Church". Athanasius is considered to be one of the four great Eastern Doctors of the Church in the Roman Catholic Church and in Eastern Orthodoxy he was the first to categorize the 27 books of the New Testament that are used today [28], [29].

Origen of Alexandria $(184-253 \mathrm{CE})$, was an early Christian intellectual, ascetic, and theologian who was born in Alexandria [30]. He was a productive author and wrote over a thousand treatises in a range of diverse branches of theology, including textual criticism, biblical exegesis and hermeneutics, homiletics, and spirituality [31]. He was one of the most significant personas in early Christian theology, apologetics, and also asceticism as well as an initiator of historical philosophy [32]-[34]. He was the first theologian to advance Christian doctrine systematically (especially the Old Testament) and was referred to as a master of allegory and "the greatest genius the early church ever produced" [34].

Tertullian $(155-220 \mathrm{CE})$ was also a very fruitful early Christian author from Carthage in the Roman province of Africa [31], [35]. He was the first Christian author to produce an all-encompassing body of Latin Christian literature and created the term 'Trinity' [36] was also a Christian apologist and campaigner against heresy and Gnosticism [37]. Tertullian has been termed as "the father of Latin Christianity" [38] and also "the founder of Western theology" [39], [40].

The last example offered is that of Antony the Great (251 -356 CE), who was a hermit and Desert Father. This Christian monk from Egypt is considered to be the originator and father of organized Christian monasticism and is consequently known as the Father of All Monks [41], [42].
The ascetical sermon in The Life of Saint Anthony by Saint Athanasius (Sections 16-34), could be termed the first monastic Rule.

Through these above stated individuals who lived in indigenous African communities, great things came to Christianity. Thus, via the mere handful of persons mentioned above, one can correctly argue that a multitude of ideas on Christian faith issues and even Orthodoxy per se rose up out of the Africa. Alexandria was undoubtedly a vibrant city promoting Christian theology during period of the Early Church and was almost certainly a very important place in which Christian theology developed and then spread to Europe from the Nilotic and Numidian cultures [18].

The Eastern Orthodox Church of Alexandria and Coptic Orthodox Church of Alexandria which disconnected from one other during the Chalcedonian Schism, in Egypt. The Orthodox Tewahedo Church split into the Ethiopian Orthodox Tewahedo Church and Eritrean Orthodox Tewahedo Church in the Horn of Africa, and they remained as key promoters of early Christianity. The Ethiopian Empire was the only region of Africa to survive the expansion of Islam as a Christian state (History World, n.d.). Christianity established itself in North Africa in the first few centuries CE and it moved in varying degrees from a relatively solid footing in North Africa into the rest of the continent [12], [43]. For the faith to be practiced and have the same essence, the second century church crafted the word ecumene (the occupied world) to suggest a commonality of Christians globally. This implied that the faith would be understood in similar fashion wherever it was accepted. For example, the notion of inter alia the Triune Godhead would resonate equally universally and so the faith began to be disseminated [44]. People soon worshipped in other parts of Africa, Syria, Asia Minor, Achaia (which was a province of the Roman Empire, consisting of the Peloponnese, Attica, Boeotia, Euboea, the Cyclades, and parts of Phthiotis, AetoliaAcarnania and Phocis), and also Italy. Moreover, there were robust leadership structures in place in places such as Alexandria, Carthage, Hippo Regius and Ethiopia [45].

Christianity gradually spread into North Africa and then South East to Ethiopia. In North Africa, Christianity became the religion of opposition against the increasing Roman Empire. It was then in the 4th century CE that the Ethiopian King Ezana made Christianity the official religion in Ethiopia and in $312 \mathrm{CE}$ the Emperor Constantine made Christianity the sanctioned religion of the Roman Empire. The severe atrocities perpetuated against Christians in earlier times must have impelled them ever nearer to their triune Godhead. Interestingly, the Ethiopian church community in the Horn of Africa was not developed due to European missionary work, but rather African missionaries. Christianity was growing in the powerful kingdoms of Nubia (ancient Sudan) and Ethiopia.

Christianity in North Africa and Egypt flourished as it offered a new habitus which accepted all cultures and embraced diversity. Tertullian in his Apology mentions clubs and associations which embraced all believers [40]. It is apparent that the North African Christians strongly influenced the church in Rome in its policies. In Nubia and also Ethiopia, the king or emperor determined the religion of the people and accepted Christianity. From persecuted to 
favoured, Christianity found itself with a new status and gradually spread westwards to the Berber population. However, at this time, the Romans were merciless towards the early Christian Church and many adherents of the faith were martyred. Christianity became the official religion of the Roman Empire under Constantine the Great, but the Berber Christians remained defiant against Roman authority. Some four hundred north African bishops called Donatists rebelled against Roman Christina Church authority [46]. Donatism was in essence a heretical sect of early Christianity, created by Donatus Magnus, who held that sanctity was obligatory for church membership and administration of the sacraments. It grew out of the persecutions of the Emperor Diocletian in 302CE. and the Donatist schism became a heresy which lasted for approximately 100 years until approximately 411CE when a Synod brought it to an end [28]. Those opposed to the Donatists opponents, such as Augustine, held that the unfitness of ministers did not nullify the sacraments, since their minister was ultimately Jesus Christ [47].

In these first few centuries, African Christian leaders such as those mentioned earlier, influenced the Christian world beyond Africa as they responded to a range of challenges posed by, for example, inter-alia Arianism, Gnosticism, Manichaeism, the Triune Godhead issue, exegetical methods, ecumenical councils, monasticism, Neoplatonism and of course the range of African literary, dialectical, and rhetorical traditions [18]. In fact, some of the central role-players in Neoplatonism were African, inter alia for example Plotinus and Philo. The African theologians and Church Fathers advanced many aspects of the faith such as inter alia the definitions of Christology, teachings on ordination, penitence and even scriptural exegesis. In addition, they greatly enhanced social thought [13], [48].

Oden [18] states:

Africa played a decisive role in the formation of Christian culture. Decisive intellectual achievements of Christianity were explored and understood first in Africa before they were recognized in Europe, and a millennium before they found their way to North America. Christianity has a much longer history than its Western and European expressions. The profound ways African teachers have shaped world Christianity have never been adequately studied or acknowledged, either in the Global North or South.

\section{The ChANGING LANDSCAPE}

Due to the growth of Islam in the 7th Century CE, and the separation of North Africa from the Byzantine Empire, Christianity lost ground, but managed to endure as the preferred religion of the Ethiopian Empire which developed the faith in its own idiosyncratic way [49]. Nonetheless, Christianity persisted in parts of North Africa albeit in a limited fashion [50]. Nthamburi [43] argues that the while Donatists and Catholics fought like cat and dog for recognition and ascendancy in a collapsing Roman Empire, and as the Catholics failed to evangelize the Berbers who were the indigenous populace of North Africa, this left the door open for Islam which was able to grab a foothold. Consequently, Christianity to all intents and purposes disappeared. Even Egyptian Christianity became pressurised by Islam's growth and by the persecutions of the Roman imperial structure. There was also no effective monastic tradition to support the faith in north Africa except for the Copts in Egypt [49]. The Berbers were also a problematic aspect due to their fight against assimilation by both Roman and Byzantine Empires [51]. The Monophysites made inroads into Nubia and promoted their monastic tradition as well as their very idiosyncratic doctrine. Along the upper Nile, this group flourished and outlived the 7th Century CE Arab invasion [52]. Then somewhat of a hiatus followed.

The 15th Century CE was a major turning point when Roman Catholicism from Portugal found its way around the Cape of Good Hope [53]. Portuguese expansion into Africa commenced when King John I sought to gain access to the gold-producing areas of West Africa.

Bartolomeu Dias (1450 - 29 May 1500), the Portuguese mariner and explorer rounded the southern tip of Africa in 1488 and his discoveries established the sea route between Europe and Asia [54]. After this, other explorers such as Henry the Navigator and Vasco da Gama drove maritime discoveries and maritime expansion around the Cape of Good Hope. Henry was involved in a systematic survey of Western Africa and was deeply involved the search for new routes. Roman Catholic Christian missionaries from Portugal followed this coastal exploration and its penetration into tropical Africa. Many were used to attempt to convert African rulers so that they could serve the interests of Portugal [52].

Nicolaides [55] provides one example of Portuguese colonial power intentions using Christianity as a tool. He states that:

Once stories of wealthy gold deposits reached their ears, many Europeans, especially the Portuguese, believed that Mutapa was the area in which the fabled gold mines of King Solomon, as described in the Holy Bible, were to be found. Consequently, the Portuguese who were settled in Mozambique since 1505, from which they traded in ivory and gold, were keen to expand their influence. As they believed that the gold mines of King Solomon were to be found in Mutapa, the Portuguese had by 1505 begun to explore the hinterland of Sofala. In the early 1500s, two Portuguese Priests António Sequeira and Gaspar Azevedo, were tasked with assisting the Portuguese to dominate the trade with India but in essence became simple carriers of sought-after goods between the Mutapa kingdom and India.

The more the Portuguese began to hear stories regarding the lucrative gold trade from Swahili traders, they began to amass strategic information concerning the geographical location of the gold, the quantities of gold produced, what could be bartered for gold, the African rulers in charge of the gold mining areas as well as the nature and extent of their political systems [56].

Using Christian missionaries, the Portuguese accordingly began to settle along the Mozambican Coast and gradually made their way into the hinterland. It was their strategy to gain control of as many as conceivable tactical positions in the Western Indian Ocean area. Concerning one missionary, 
Gonçalo da Silveira, it was amazing that he managed to baptize Monomotapa, king of the Shona people in the territory of what is today Zimbabwe [57]. Soon after however, Fr. da Silveira was murdered after a message was disseminated that he was a Portuguese agent and a sorcerer who had come to bring drought and famine to their lands and that he would eventually kill the king: “...the priest was a muroyi (which means a treacherous wizard), bringing sun and hunger and dead man's bone and other evil objects to conquer the land and kill the king" [58]. In addition, his sprinkling of holy water was also considered to be part of an evil conspiracy to appropriate the power of ruler in the region in which he operated. Nonetheless, the Portuguese advanced their interests further by using slave labour to work on the land they acquired under some treaties signed with local leaders. On the Eastern Plateau of what is today Zimbabwe, trading posts, mining settlements and churches gradually grew in the Mutapa Empire and by the seventeenth century, the Mutapa contributed all their gold to the King of Portugal and many people were enslaved in the process and their cultures and tribal identities were severely undermined [55].

The Jesuits were frequently challenged and harassed, but their mission endured for approximately a century, and they were able to spread the faith and instituted Catholic doctrines in the region. In the next century the ventured into the Congo kingdom, Mozambique and Angola and operated there until 1759 when their role was usurped by Portuguese imperial machinations [59]. The introduction of Christianity into a range of African communities resulted in numerous clashes as it was believed that the missionaries and the Christian religion per se, were out to "colonize the conscience and consciousness of the colonized" [60]. By 1583, the Portuguese had established themselves in Zanzibar and on the Swahili coast while the Kingdom of Congo was converted to Christianity in $1495 \mathrm{CE}$.

Founded in $1571 \mathrm{CE}$, the Dutch Reformed Church spread into South Africa with the arrival of the Dutch in 1652 CE. It was established during the Protestant Reformation and was to a large extent fashioned by John Calvin and some other major Reformed theologians. Dutch settler communities around the world gave allegiance to this denomination which became a central part of Afrikaner nationalism which developed in South Africa. There were of course also various French, English and Belgian ecclesiastic manoeuvres in Africa but for the most part, in the interior most people sustained the practice of their own religions uninterrupted until the 19th Century. The abolition of the slave trade throughout the British Empire in 1834 proved to be a significant turning point and the conversion freed slaves was viewed as essential and it became a strong motivating factor leading to the establishment of various European Christian missions. Indigenous peoples desired literacy and this made Christianity very attractive to many African people. In fact, much of sub-Saharan Africa had no form of writing until the arrival of Christian missionaries. European states developed greater colonial interest in Africa as they competed with each other and thus also used and abused religion at times, in efforts to appease the masses who they supressed. In the 1800 's, Catholic missionary expeditions were conducted in Senegal and Gabon. In 1804 Protestant missionaries also advanced into Sierra Leone [61]. The missionaries in Africa, usually driven by a sincere antislavery crusade characterized a large gamut of Christian denominations that were often in rivalry and conflict with one other.

The Protestants tended to spread the Christian faith:

...through the slaves who were liberated from slaving ships along the West Coast after 1834. The application of Christian doctrine was much stricter than it had been in previous centuries. The success of Christian missionary programmes can be linked to the education they offered. Many people in Africa wanted education; and missionaries taught people to read, in order that they might understand the word of God. Many European missionaries worked extremely hard running their missions, risking their lives and good health in the process. They varied enormously in their ability to contribute to the quality of life of those they lived with. Some remained dedicated but contemptuous of those they claimed to be converting. Others developed deep affection and respect for those they worked with and made a long-lasting impression [62].

Onyinah [63] explains that during the 18th century, the United Brethren or Moravian Church of Denmark and the Society for the Propagation of the Gospel made numerous efforts to spread Christianity but was not entirely successful. Nonetheless Christianity progressively established itself. In the $19^{\text {th }}$ and $20^{\text {th }}$ Centuries, Orthodoxy began to grow again in Africa and many people of Greek extraction went to settle in different parts of Africa. Schools and printing presses were established to sustain the Greek language and heritage and Orthodox missions were created [64]. A renewed missionary effort was enacted by Pope Petros VII. During his seven years as patriarch (1997-2004), and he worked diligently to spread the Orthodox Christian faith in Arab nations and throughout most of Africa [64]. He ordained native clergy, promoted missions, and encouraged the use of local languages in the liturgical life of the church. He was also very tolerant of diversity and was sensitive to the way in which Christian expansion took place in Muslim countries. He was basically a promoter of mutual understanding and respect between Orthodox Christians and Muslims. Despite numerous points of friction, he also worked to improve ecumenical relations with the Coptic Orthodox Church [65]. Christianity with its use of missionaries undoubtedly contributed immensely to the improvement of African society. For example, “...the establishment of schools, the introduction of Western medical systems, and social advancement of African society, such as the abolition of capital punishment and slavery. In addition, the missionaries were responsible for promoting translation, including the creation of vernacular alphabets and production of grammars and dictionaries" [63].

Roman Catholic Portuguese missionaries in Angola and Mozambique on the other hand became notorious and feared for their inclination to work with the Portuguese colonial authorities and were viewed at times with suspicion. The result was that some Protestant missions grew popular in countries such as Angola and Mozambique's and their schools played key roles in providing sought after education facilities [66]. The British missionaries for the most part played a key role in promoting the extension of Britain's Empire. 
Similarly, most German missions were used knowingly or not, to safeguard German commercial interests [67]. In the 19th century there were also some missionary activities carried out by organizations including the Basel Mission, the Bremen Mission, the Wesleyan Methodist Society, and a number of Catholic missions. The 19th-century missionary activity was mainly the result of Protestantism with all its desire, passion, and commitment to spread the word [68].

African evangelists were always vital elements in European missionaries' efforts to proselytize Africans in the late $19^{\text {th }}$ century. It was often the case that Africans evangelised other Africans who became converts who served as translators, concierges, guides, and assistants among other jobs [69]. They helped to facilitate the process of evangelisation. Ultimately, it was the contemporary missionary crusades and indigenous Christian movements in Africa of the nineteenth and twentieth centuries which built upon the foundations established by earlier Christian initiatives. Present-day Pentecostal and charismatic Christianity is bringing in needed renewal to the church in Africa. It is clear that European cultural values and Christianity have given many Africans a new sense of spiritual security and social purpose. It needs to be stressed that mainly Africans were instrumental in the growth of churches despite the fact that for example, the first African Catholics Bishops were not appointed until 1939. In the rest of Africa, African missionaries were appointed by the Presbyterian Church in Cameroun in 1896. Many Africans such as John Chilembwe (1871-1915) who was a Baptist pastor and educator in Malawi, studied in America and returned to preach the Gospel of Jesus Christ and established independent African churches.

In much of Africa south of the Sahara, the growth in Christianity commenced as a result of missionary enterprises by Western Christians including Roman Catholic, Orthodox, Protestant and the Anglican Church Missionary Society and more so especially in the $20^{\text {th }}$ Century. These missions came from France, Germany, Holland, and also the United States [67]. Today Christianity is embraced by the mainstream of the population in most of the states in Southern Africa, Southeast Africa, and Central Africa. It is also popular in parts of Horn of Africa and West Africa. In the main, missionaries viewed themselves as the guardians of Africans' human rights and worked vigorously towards fighting exploitation of African workers under colonial rule [70].

As Catholicism lost ground in the late eighteenth century, a new force in the form of Evangelicalism came to the fore. Christianity was now viewed as a movement of spiritual revival and also as a force for justice which has enthused millions on the continent. It emphasizes the 'good news' of the gospel of Jesus Christ. Through personal encounters people become transformed. There is an “...existential transformation of the individual that brings salvation and with it certainty, well-being, purpose, meaning, and joy... The existential reality of Africans is that they live in a world that is powerfully influenced by forces that are both modern and pre-modern. Evangelicalism enables them to transact between these forces in a way that many clearly find at the least helpful, at the most liberating" [71]. "There are two significant trends in Christianity in Africa since independence. First, the emergence of a large African theological fraternity composed of both Catholics and Protestants. Second, a new missionary zeal on the part of the African church" [1].

Christianity was an important agent of great change in Africa despite it being mistrusted to an extent due its linkages with colonial overlords. It however brought in new opportunities to many, and also often disrupted the status quo while diminishing the power of others in various countries. Christianity brought with it a measure of education, literacy, and anticipation of a better life in the now and hereafter, for especially the underprivileged and marginalised in societies. Increasing literacy and numeracy was non-negotiable as a missionary activity as teachers had to be trained to promote the faith [70]. It was mainly the Protestant churches that promoted education since adherents had to be able to read the Holy Scriptures. In this regard the Lutheran Church played a great role [72].

There are currently nearly 685 million Christians in Africa, with 760 million expected by 2025 [73]. However, there is also currently a strong African consciousness and critical approach to Africanise Christianity, which means it must be decolonised and indigenised as far as possible [74]. In the post-colonial period of the 1960s, numerous African governments that were previously critical of the church requested assistance from churches in efforts to nation-build and by the early 1990s, many new nations had a strong want to work together with churches [1], [75]. In the 1990s, charismatic Christian groups transmuted the face of many African Christian traditions and began preaching messages of healing and power which grew church numbers exponentially. Consequently, churches of Pentecostal origin are the fastest growing [1], [76], [77]. While Christianity was certainly an agent of positive change in Africa, it also destabilised indigenous communities and undermined their beliefs and thus also brought negative aspects. In some countries such as for example the Congo, the church had a robust anti-colonial approach. Nonetheless over the years there has been an increased drive towards an indigenised African identity for several local and 'imported' churches and local churches in Africa continue to be founded and are flourishing.

The range of Christian missionaries from diverse denominations were obliged to spread an understanding of their Christian gospel in the native language of the indigenous people they wanted to convert. The Holy Bible was thus translated and communicated in indigenous native languages but many of the Christian schools taught English and promoted values characteristically found in Western culture [77]. Nonetheless, Christianity, both as a religion and as an institution which is concerned with an ethical life, has made a huge contribution to education in mainly sub-Saharan Africa. Democratic ideals also spread due to Christian missions and economic growth was also supported. In addition, there was an increase in a middle class in many countries [72]. Nonetheless, while many missionaries claimed to be protecting indigenous peoples and their interests, some missionaries them simply promoted the interests and culture of their colonial controllers. Jomo Kenyatta maintained that "...when the missionaries arrived, the Africans had the land, and the missionaries had the Bible. They taught us to pray with our eyes closed. When we opened 
them, they had the land, and we had the Bible" [78].

The development of missional ecclesiology encouraged the critical role of the sending of missionaries and their particular cultures in what was often viewed as a type of neocolonialism. Health in Africa improved due to missionary activities which safeguarded those hospitals and other related facilities were built where they operated [79]. In the current world, missionary work is incompatible for reimagining the spreading of the word of God in a postcolonial, post-Western, post-Enlightenment, post-Christendom, and post-mission era [80]. It should also be noted that Africans searched for characteristics of Christianity that could more closely align with their own religious practices. Generally speaking, there were and are of course some similarities and differences between Christianity and indigenous African religions which are looked at in the next section.

\section{SOME SIMILARITIES AND DIFFERENCES BETWEEN CHRISTIANITY AND AFRICAN TRADITIONAL RELIGION}

African Traditional religion supports a moral life imperative and is commonly grounded based on oral traditions, through which basic values pass down through the generations and forge a strong cultural identity. Storytelling, fables and myths as passed on by the elders and are for the most part, considered to be very important as is a communal lifestyle in which traditions and heritage are maintained. Africans view religion as part and parcel of life, and it is a typical way of looking at the world and what it offers from day-to-day. As is the case in the Christian religion, traditional African religion has organised observances. There are various essentials comprising African traditional religion and they include beliefs, ceremonies and festivals, objects and places, values and morals, and religious officials [81]. The range of traditional beliefs and practices of African people are highly diverse beliefs and includes various ethnic religions. The traditions observed are predominantly oral in nature and passed down from one generation to another through folk tales, songs, and various festivals.

While Christianity was devotedly adopted by many people in Africa, there were often tensions between indigenous populations and the missionaries from the west who generally regarded Africans as being primitive in their religious activities. Nonetheless, many aspects of Christianity were quite familiar to people coming across it for the first time. For example, the ideas of a supreme being, the material world and the spiritual realm, the idea of revelation and prophesy through the mediums of dreams and visions, all existed in traditional African religions. People could find redemption through sacrifice; Christ's sacrifice has a resonance in sacrificial rites of traditional African religions [82], [83].

For an African believer, there is no separation between domains of authenticity. Followers believe in the guidance offered by ancestral spirits. Thus, otherworldliness is a vital part of reality viewed through a lens of daily life and 'the universe is perceived as an organic whole' but people keep the linkages between 'visible and invisible spheres of the universe' [84]. The notion of a unity of body and spirit was of course also part of Greek philosophy. Plato, in various dialogues, argued the true self of a human being is the reason or the intellect that constitutes a person's soul and that is separable from the body. Aristotle, however argued that a human being is a fusion of body and soul, and that the soul cannot be separated from the body [85]. Wernhart [86] asserts that ancient Greek philosophy and Hellenistic anthropology, articulate aspects which also apply to African Religion.

In African thought the notion of transcendence is that it is used mainly in the milieu of religious and spiritual things and all human beings "continually surpass themselves in all they are, all they wish and all they have" [87]. One should however strive to conform with local understandings and values. For the African, transcendence also denotes a God who is worshipped and viewed as a life-force [87]. Considering the nature of being then, God as the Supreme Being is ontologically transcendent. Carmody [88] states that in an African understanding of religion there is a unity of all that is present and also an equality of essence of all things. Thus, Humans transcend, but are in the world and very much part of it.

Christianity as well as African traditional religions accept that God reveals Himself to people through dreams, prophecies, and different proceedings. In modern Christianity however, there is no place for magic and witchcraft which are viewed as being of an occultic nature and thus contrary to the word of God. An acceptance of the belief in occult forces is still intensely rooted in some African societies, irrespective of the level of education, religion, and social class of the people concerned [89]. A belief in what is termed "black" magic, or witchcraft, is used to harm others for egotistical purposes, and this is the most problematic aspect of this belief. Consequently, "Christian churches, are convinced that witchcraft constitutes a real threat to society in Africa" [68].

Magic and witchcraft linked with the occult were also serious points of contention with missionaries in Africa although witchcraft as such, was also widely practiced in Europe and elsewhere and was a basic part of the world view of various people beyond Africa. African Witchcraft is articulated in different forms, and this is generally according to region, religion, or ethnic affiliation [68]. Kingsley [90] considered African witchcraft to be a rival to religion and did not reconcile it with African traditional religion which attempted to uplift human beings above all other things. Traditional African religion recognises a supreme being, followers do not worship the supreme being directly as they often consider themselves to be unworthy. Thus, ancestors are called upon to communicate on their behalf. The supreme being is the ultimate connection between all humans and their natural environment. Traditional healers are invited to serve by the ancestors and are viewed as spiritual leaders in most African traditional religions and their role is to heal the infirmed and they delve in divining after having gone through an apprenticeship where they learn to use herbs for healing and a range of other mystical skills such as foretelling the future.

Kingsley further depicted the African 'witchdoctor' as an evil person who relied not on "...his own secret knowledge and experience of the effect produced by certain tricks and mysterious devices upon the unseen powers, over whom he has obtained a sort of command [90]. Beliefs in witchcraft formed and still form a part of the functional viewpoint, which included principles and approvals for social control as well as serving as regulatory instrument for conflicts and 
social change. Witchcraft has an assortment of social functions in African societies and is to all intents and purposes a response to local social needs [91].

In several African cultures then, people often believed in the control of one's life by the use of a talisman, magic and what were termed witchdoctors, sangomas, traditional healers or medicine men [92]. People greatly feared them but still consulted traditional healers who would usually use various herbs and charms to cure a range of maladies, ritualise rainmaking and offer a range of magical treatments for agricultural problems and other issues of concern. Most ancestral spirits are considered to be benevolent but can become malevolent and cause illnesses to warn people that they have transgressed. In such cases the ancestors need to be appeased through offerings.

Christians recognise the reality of magic and witchcraft but expect a believer to visit a doctor and pray for healing when ill. However,

witchcraft in Africa is part and parcel of the whole complex of religious ideas on a level with the belief in punishment from the ancestors or the automatic disastrous results of breaking ritual restrictions. This complex can allow for the possibility that human volition may justifiably cause mystical harm as a punishment. The detection of witches is done by men who though not priests, can certainly (sic) be thought of as having religious functions [93].

Missionaries condemned some traditional dress and even dances and called for the destruction of all objects or animals which were worshipped by Africans. African Christians also often opted to worship without the presence of any European mediators, and in a manner that they saw fit to do so, and this was viewed as a serious affront to the missionaries, priests and pastors.

"The Kimbanguist church believed Jesus was black and regarded symbols with different weight than the Catholic and Protestant Europeans. The common practice of placing crosses and crucifixes in churches was viewed as a graven image in their eyes or a form of idolatry" [94]. Traditional Africans made images of a supreme spirit or God and any other supernatural beings which they adulated. For example, some would create images a lion or other animals carved in wood or even wore masks that came to represent a deity. This was viewed as idolatry by Christians. Where there was "animism" or "fetishism", an array of ritual activities with natural objects as deities, missionaries attempted to eliminate such a religion [95]. They viewed it as being based on delusion and strove to convert Africans to the Christian God.

From a Christian perspective, a stationary view of God turns the divine being into a lifeless, sterile, and immobile entity. The inward-looking nature of idolatrous cultures stems from their parochialism, which tends to make a religion less transportable. The parochial tendencies thus invariably restrict the local dominion of evil and demonic spirits as they are not like the Judaeo-Christina God who is omnipresent or omniscient [96]. The Yoruba who today live in Southwestern Nigeria, believed in the existence of the supreme deity termed Olurun and also a minor god, Obatala. They accept as true that Obatala helped Olurun in creating the world and everything in it. Obatala is believed to be the Sky Father and the creator of all human bodies, which were brought to life by the breath of Olódùmarè. Christians on the other hand accept only the Triune Godhead as a Superlative Being and Creator. It seems from the cult performances of the Itapa festival that Obatala was a dying and the rising god. "He left his temple in the town on the seventh day of the festival, stayed in his grove outside the town's precincts on the eighth day, and returned in a great procession to his temple on the ninth day" [97]. According to one of the Yoruba accounts of the creation, at a certain phase in the course of human development, the "truth" was sent to confirm the habitableness of the planets that were newly fashioned [98]. To Christians, Jesus Christ is the Truth which sets us free. There are no other gods apart from the one and only God. In African belief, myths and the rituals in religion are transferred from one generation to another to guarantee the continuation of a tradition. Myths are analogous to a vehicle that ensures the transmission of tradition from one generation to another [84].

The beliefs of ancestral worship and mediation to guardian spirits point to territorial bondage and ethnic elitism while people remain imprisoned to a locality. These gods, spirits and ancestors reside in a particular object or territory and protect people who reside within its vicinity. Their powers do not extend beyond those areas, and when people travel to distant places, they are no longer under the protection of their gods and expected to change their allegiance to a stronger God of the new region and serve him. In contrast to tribal spirit deities [96].

Hiebert [99] argues that in Christianity, God has declared that he is not a territorial god but the God of the Cosmos. He exists in a Triune Godhead of Father, Son and Holy Spirit and is universal.

In terms of sacrifices a number of traditional African religions promote the notion of bird and animal sacrifices to appease a deity whenever people seek to venerate their god/s. In Christianity, adherents do not offer animal sacrifices to appease God. Jesus Christ died for sins once for all at Golgotha: "For Christ died for sins once for all, the righteous for the unrighteous in order to bring you to God" (1 Peter $3: 18$ ). Thus, Jesus died for our sins, once for eternity. Christians generally attend a church to worship God and also do so from their homes and anywhere they may find themselves. In traditional African societies people had to go to sacred places to worship their divine entities. There is also ancestor worship in which there are elaborate funerals and burial rituals of the dead. Ancestor veneration centered on the ancestors and all the various deities and living descendants are genetically linked to their ancestors. There are "festivities of honor with music and dances to provoke ancestors and deities into joining in the celebration" as there is a belief in the eternal existence of their souls as ancestors, and also the deities [100]. There are of course many varieties of worship among African societies, and it tends to differ slightly from one area and society to the next. Even the way in which a sacrifice is being offered may diverge. Where there are offerings given, these are for personal and communal reasons and such are normally made at sacred shrines or in sacred 
groves, or other holy places, including inter-alia hills, lakes, waterfalls, while personal offerings are generally made in the home [101]. There is episodic commemoration of ancestors, as there exists a belief that they influence the affairs of their living descendants.

As in Christianity, the priest in African traditional religions is the principal intermediary and spiritual and ritual expert who stands between the divine and humanity. He or she symbolizes God among his or her people. Priests are tasked with performing rites, attending ceremonies, and also offering of prayers for the blessing of people in need. There are some points of divergence though as the African priests also making potions, sacrifice and may also communicate with the spiritual world by acting as a medium or having other individuals serving as mediums [102]. Priests in African traditions have various characteristics such as belief in a supreme being, belief in spirits and divinities, the cult of ancestors, the use of magic, charms, potions, and spiritual forces [103]. Sundermeier [10] explains that rituals become highly symbolic actions that outline the associations in which humans stand with the divine, the ancestors or spiritual beings and with nature and human relationships.

In African society, it is often acceptable for a human being to have multiple wives, but in Christianity, polygamy is not permitted at all [82]. Missionaries thus principally condemned the African acceptance of polygamy and were at loggerheads with locals. Beyers [105] argues that an African understanding of religion cannot be reached through Western eyes. It clearly stresses a holistic approach to life which may vary from culture to culture and locality to locality. However, religion is very important including all the rituals and myths and these all need careful scrutiny to be comprehended rather than being cast aside as 'witchcraft'.

There are often conflicts that arise between traditional religion and Christianity in African countries that are based on moral and ideological standpoints, and sometimes these become physical, due to issues of conscience experienced by individual Christians living between the creeds of Christianity and those of an indigenous traditional religion. There is sadly sporadic destruction of lives and property and demolition of the people's religious and other artefacts and groves by Christians, and this has led to a decrease in the sources of economic generation of traditional religionists [106], [107]. "It has also led to syncretism in the people's culture and has given rise to disintegration and lack of unity among the people. Sometimes, to avoid conflict, many families now combine the tenets of the two religions. For instance, after performing the full traditional marriage rites, the church wedding will follow. The same goes for burial and other social ceremonies" [107].

In traditional Africa society as in Christianity, religion has organised practices with initiation rites into full membership and there is also a belief in reconciliation with a supreme being [108]. The most practiced method to approaching God is through three forms of prayer which may be completed privately, by individuals, or by heads or their families. Within the family, a prayer is normally completed by the head of the family and often the oldest member of the family, but occasionally a ritual elder or local priest may be requested to conduct a prayer. Prayers are offered as praise-poems which are often a panegyric or hymn where there is thanksgiving.
Prayers are also offered communally as a litany or call and response prayer form in which a person, usually a leader of some sort makes invocations or intercessions, and a choir or congregation makes a formal response or exhortation. The ritual formula form of prayer is typically a short vocalization in the form of a petition complementing some ritual action [6]. People such as priests, rainmakers, chiefs, and sometimes medicine-men or medicine-women also pray on behalf of others. In fact, when it comes to gender equity as an aspect of faith leadership Mazrui, stresses that Kimbanguists respected the roles of women in church more than Orthodox churches and Catholic Churches and afforded women the roles as priests and preachers [94].

Traditional Africans communicated to God through ancestors. They did this as they offered libation by pouring water or any other drink to the ground. Christians pray to God through Jesus Christ and the Holy Spirit and in essence then the Triune Godhead without any potion required [3], [109].

Christians in especially the Pentecostal Churches offer a tenth of all their earnings to God as a commanded obligation to regularly give to a church based on income. Other Christians of course do also give as they are able to and feel the need to. In Malachi 3:8-12 the Israelites were accused of stealing from God in terms of non-payment of tithes and offerings, for which reason they are under a curse. Some churches in teach that tithing is obligatory for Christians, and that non-payment of tithes brings calamities to defaulters who are greedy and selfish [110]. In Africa with its estimated population of 1.2 billion people, a substantial percentage lives below the poverty line, and many face hard-hitting economic times and basically make ends meet, so tithing is virtually impossible. Many Christian church denominations do support vulnerable people rather than allowing the vulnerable people to support them. By contrast, Traditional African religions adherents may make offerings when and if they are able to, but they do not tithe as such.

\section{THE NOTION OF THE EKKLESIA AND LAOS OF GOD}

The term Ekklesia means both a specific body of faithful people or an assembly of Christians gathered for worship in a religious meeting, and also the entire global body of the faithful or the whole body of Christians dispersed throughout the earth-including the dead. The term comes from ek, in Greek, meaning "out from and to" and kaleo, meaning "to call," and has to do with an assembly of people called out from one place and to another. It is thus an assembly or a congregation. The Ekklesia in the New Testament is then a group of people who have been called out of the world and to God universally. The Universal Church is thus also termed as the Ekklesia in Greek, and this also alludes to the Kingdom of God. It is the theanthropic body of the Lord, whose head is Christ, and its members are the faithful, irrespective of which race they are part of or on which continent they reside. This body is a living organism comprising God's life inside humanity and the world.

Within the Church, we become one body with Christ as we partake in the divine life and strive for thesis as we approach the triune Godhead. We gather in churches to build the body of Christ, not independently, but as united people in a community of believers. It is not a religious gathering in a 
fixed place but rather a spiritual union with brothers and sisters in the Lord. We are called "to gather together in unity the scattered children of God" (John 11:52). In this sense then we become the laos or nation of God [111]. In the NicenoConstantinopolitan Creed completed at the First Council of Constantinople in $381 \mathrm{CE}$ it was accepted that "[We believe] in one, holy, catholic, and apostolic Church" [112]. This affirmation of the Christian faith should guide us in accepting traditional African churches which accept Christian dogma fully, as being equal in status and intent to any other churches given that we are all part of the body of Christ.

In Matthew 16:18 we read "...And I say also unto thee, that thou art Peter, and upon this rock I will build my church; and the gates of hell shall not prevail against it". This is irrespective of where it is situated. In Romans 16:16 it is stated we ought to "Salute one another with a holy kiss. The churches of Christ salute you". Thus, church buildings with people in them are to be united in the Church (Ekklesia) of God. The church is "called out." Second Peter 2:9-11 pronounces, "But you are a chosen race, a royal priesthood, a holy nation, a people for his own possession, that you may proclaim the excellencies of him who called you out of darkness into his marvellous light. Once you were not a people, but now you are God's people; once you had not received mercy, but now you have received mercy. Beloved, I urge you as sojourners and exiles to abstain from the passions of the flesh, which wage war against your soul." Jesus said we are to be as salt and light in the world (Matthew 5:13-16) consequently we are to add 'flavour' to humanity irrespective of its physical space. Jesus Christ is the head of the body, the assembly" (Colossians 1:18) and we are required to follow His will. The church fathers held that God the Father, the Maker of all things visible and invisible, had to be above his creation in both nature and substance. "They believed that the Creator could not have the same substance as the created order, for his nature should be superior. Therefore, if Jesus was not created, he is not part of creation but part of the Creator. And if Jesus is part of the Creator, he should be 'of one substance with the Father, Light of Light, very God of very God, begotten not made" [113]. Moila [114] maintains that "Western Christianity had failed to meet the African aspirations" and it "has taken from Africans a religion which was functional and useful in their lives". There are however important differences as stated earlier.

Though we live in the world and are part of it, the church is meant to be distinct and must separate from the ways of the world and point to the truth of God and speak to facts of our faith as they were and are. We are to love all people on all continents as God does and share His invitation to salvation with them. We should pray that all people, will hear His call and join His church and become spreaders of the Word in their unique geographical and cultural contexts. Hebrews 10:23-25 advises us, "Let us hold fast the confession of our hope without wavering, for he who promised is faithful. And let us consider how to stir up one another to love and good works, not neglecting to meet together, as is the habit of some, but encouraging one another, and all the more as you see the Day drawing near". We need to lovingly "Shepherd the assembly of the Lord which He acquired for Himself through His own blood" (Acts 20:28) and not arrogantly assume that churches in the West are superior in any way to those in
Africa or elsewhere. After all, the early church fathers emanating from Africa perceived pain and suffering as a consequence of sin, due to mankind's defiance towards the creator. They totally accepted that salvation is only through the Lord Jesus Christ who became human, suffered for our salvation and who is coming back to be the judge of both the living and the dead.

\section{A NEED FOR RETHINKING HOW TO AFRICANISE CHRISTIANITY}

African traditional religion has a right to exist inside the Christian faith provided that Christian truths are not manipulated to meet local conditions, but rather kept in situ. Nonetheless, there are numerous scholars and theologians who believe that there exists a dire need indigenize the Christian faith. Maluleke [115] says that Africans should not be experiencing Christianity as an estranging and western belief system. He calls on churches to revise their institution, theology, doctrine and worship if they are to be indigenised churches. Indigenization calls for the integration of Christianity with the local philosophies, language, principles, customs, traditions and beliefs. If this is not done, Christianity will be viewed as a Western faith being imposed on Africa [116]. Africa is in need of its own Christian identity from a religious perspective and only by obtaining this will it be free of perceived colonial subjugation to western powers [18]. When African states lost their autonomy under colonialism, traditional African religion came to be viewed as portraying an Africa that had been subjugated by colonial overlords thus paving the way for many to embrace Christianity so as to liberate themselves, but many did not necessarily abandon their earlier basic religious beliefs. In this era, Christian missions spearheaded African aspirations for foreign language skills and knowledge acquisition. Conflicting values undoubtedly plagued many Africans as the worshipped Jesus Christ but also maintained some of their earlier practices [117]. Setiloane argues that there is a need for an inclusive understanding of divinity in African theology that incorporates the living as well as the dead [119].

Setiloane thus challenged and engaged with the Western theological discourse on the structure and function of divinity. He supported the notion of an African theological discourse. He discovered that African Christians in fact tend to Africanise the Christian Western God concept and thus raise it to the level of their concept of Modimo, which is viewed as loftier, as expressed below:

So, my sweet old lady Methodist Manyano woman informant at Lobatse says: "We have learnt nothing new about religion from the missionaries. All they have taught us is thabologo Western civilization and way of life."' But we are bringing something to Christianity: a view of Divinity much higher, deeper and all pervasive. That is why we quarrel so much with our Christian brothers at Ecumenical gatherings. Our expectations from Christianity are different because we come with different presuppositions and different views of the over-ruling determining Divinity, which we all together profess to confess in the Christian fold [119]. 


\section{Setiloane goes on to say:}

With our higher understanding of Divinity than Western Christian Theology why are we continuing in the Christian fold? I must confess that these days I even find an Ecumenical Bible Study session with my Western Christian Theologian brothers rather irksome and a bore. Not only why we remain in the Christian fold but as one West African Christian young man asked me in Bezel: "Why do we then continue to seek to convert the devotees of ATR?" [119].

Setiloane found it rather difficult to get away from the Christian 'witchcraft' with which Africa had been bewitched for more than 150 years [120]. Setiloane staunchly supports the idea that African divinity requires African scholarship undertaken by Africans themselves. This should incorporate inter alia work into Pneumatology and African Divinity [119]. Maluleke [115] also in similar vein, contends that Africans need to understand Christianity as also being African and not only Western. Since many African Christian devotees are still grappling with transformation in their churches. They reside in Africa but practise their faith in line with Western principles and are alienated from and essentially abandon their traditional way of life and rich heritage [121]. Churches such as the Protestants and Roman Catholics have worked to promote a non-sectarian approach to spreading the faith on a Pan-African and also ecumenical level. For example, African Theologians convened in Ibadan in 1969 under the auspices of the World Council of Churches and many other meetings have taken place since including symposia on themes such as African Mediations of the Sacred Rites and Religious Language (1986). In these varied meetings, the theme has been to explore the theology of traditional African religion relating to inter-alia, the nature of a supreme being, prayer, sacrifice, rituals, and worship in general. Efforts have also been made to forge an African liturgy and distinct sacramental rites, assessing the African musical style for church usage, marriage, baptism and even funerals in terms of African family institutions etc.

An inculturation of the Christian faith has resulted which presents and re-asserts the Christian gospel in alignment with various cultures and this invariably leads to a re-interpretation and an enrichment of both [122]. Christians of all denominations and races should take careful note of the huge contribution to the faith as made by early Church Fathers emanating from Africa. They also need to understand that Africans are now spreading the gospel in Africa and exalting the Holy Trinity in their own often unique ways and in line with their own awareness and cultural terms [123], [124].

\section{CONCLUSION}

Paulo Freire the renowned Brazilian Catholic educator and philosopher was hyper-critical of teachers who considered themselves to be the sole possessors of knowledge and viewed their students as empty 'vessels' into which they were required to deposit their knowledge. In the same manner, colonisation brought the Christian and other religions to people and the colonisers assumed that they were the sole possessors of a valuable faith and culture which should be embraced by all. They arrogantly viewed indigenous cultures as being inferior. Freire maintained that people should be able to solve their own problems based on their own understandings. Thus, in the case of Christianity and any other religion being passed on to others, a pluralist responsiveness is needed which resects diversity. It is only by respecting the otherness of people with indigenous traditions that a true Christian praxis and consciousness can develop [125]. Christianity must be seen as being relevant for all people as they face a myriad of challenges in life. It should also be understood and re-emphasized that God communicates with all people in a manner that they can comprehend [123], [126].

There has always been a dire need to spread the gospel in a manner which is able to permeate African ways of life, in this regard inculturation is necessary [127]. This is especially given the great influence of Africa on the Christian faith from its inception. There will of necessity be a need for consultation between all Christian stakeholders regarding inculturation so as to be 'on the same page' as it where, in promoting the common faith and truths of Christianity.

While Christian missions served as promoters of the faith, offered education, and promoted democracy, there were many that operated either, knowingly or unwittingly, as agents for colonial oppressors who exploited Africans. Holy Scriptures cannot be taught without appropriate actions being demonstrated and role modelled by the "teachers". Christianity must be made relevant for indigenous peoples in their milieu [128]. Shorter (1973) argues that '...there is no Christian value that is not a human value expressed differently in another cultural milieu' [129]. There must however be no modification to the truths presented by Christianity based on the authority of the Holy Bible, the teachings of the Early Church Fathers or even Holy Tradition. The Spirit of God moves ecumenically and should be embraced as such. Christ invites us to embrace all in a spirit of agape love as we pass through this existence to His Eternal Kingdom.

\section{REFERENCES}

[1] TGC -The Gospel Coalition. (2019). The History of Christianity in Africa//Africa Study Bible, [Available online at https://africa.thegospelcoalition.org/article/history-christianityafrica/].

[2] R. Shaw, C. Stewart. Syncretism/Anti-Syncretism, The Politics of Religious Synthesis, Edition 1st Edition, London: Routledge, 1994.

[3] Kollman, P. "Classifying African Christianities: Past, Present, and Future: Part One.” Journal of Religion in Africa, 40(1), 3-32, 2010. www.jstor.org/stable/20696840.

[4] Opoku, K.A. (1993). 'African Traditional Religion: An enduring heritage', in J.K. Olupona \& S.S. Nyang (eds.), Religious plurality in Africa: Essays in honour of John S. Mbiti, n.p., Mouton de Gruyter, Berlin.

[5] Canaris, MM. (2018) The rapid growth of Christianity in Africa, Catholic Star Herald. December 13, [Available online at https://catholicstarherald.org/the-rapid-growth-of-christianity-inafrica/].

[6] Mbiti, JS. African Religions and Philosophy, Praeger Publishers: New York, 1969.

[7] Nche, GC, Okwuosa, LN, Nwaoga, TC. Revisiting the concept of inculturation in a modern Africa: A reflection on salient issues. HTS Theological Studies, 72(1), 2016 [Available Online at https://dx.doi.org/10.4102/hts.v72i1.3015].

[8] Meinardus, O.F.A. (2002). Two Thousand Years of Coptic Christianity. Cairo: American University in Cairo Press

[9] Neff, D. (2008/9). Out of Africa. Christianity Today (28 February). 
[10] Available from: http://www. christianitytoday.com/ct/2008/

[11] februaryweb-only/109-52.0.html. [Accessed 11/05/2015].

[12] Ross, E. "Impact of Christianity in Africa." Annals of American Academy of Political and Social Science, 298, 161-169, 1955

[13] Barret, DB. "AD 2000:350 million Christians in Africa." International Review of Mission, 59(233), 39-54, 1970.

[14] Stark, S. The Rise of Christianity, Princeton University Press: Princeton, NJ, 1996.

[15] Oliver, W.H. \& Madise, M.J.S. (2014). The formation of Christian theology in Alexandria, Verbum et Ecclesia, 35(1), 1-13.

[16] Burton, KA. The Blessing of Africa the Bible and African Christianity, InterVarsity Press: Downers Grove, 2007.

[17] Groves, CP. The Planting of Christianity in Africa, Lutterworth Press: London, 1948.

[18] Pearson, BA. "Christians and Jews in first-century Alexandria." Harvard Theological Review, 79(1-3), 206-216, 1986 http://dx.doi.org/10.1017/S0017816000020472.

[19] Fogarty, ME. "Egyptian Christianity: An historical examination of the belief systems prevalent in Alexandria C.100 BCE - 400 CE." Dissertation, Department of Ancient Near Eastern Studies, University of Stellenbosch, 2004.

[20] Oden, TC. "How Africa shaped the Christian mind." Inter-Varsity Press: Downers Grove, 2007.

[21] Foley, LOFM. "St. Cyprian", Saint of the Day, revised by Pat McCloskey O.F.M., Franciscan Media, 2009.

[22] Daniel, R. "This Holy Seed: Faith, Hope and Love in the Early Churches of North Africa." Chester: Tamarisk Publications, 2010.

[23] Tierney, B. "Foundations of the conciliar theory: the contribution of the medieval canonists from Gratian to the Great Schism" (New ed.) Leiden: Brill, 1998.

[24] Walker, GSM. "The Churchmanship of St. Cyprian.” Richmond: John Knox Press, 1969.

[25] Salinas, O. "The Psychological Roots of St. Augustine's Theories of Good and Evil." Biography, 15(4), (Fall 1992), pp. 348-370.

[26] Bonner, G. "St. Augustine of Hippo. Life and Controversies." Norwich: The Canterbury Press, 1986.

[27] O'Connell, RJ. "St. Augustine's Early Theory of Man.” Cambridge: Harvard University Press, 155-183, 1968

[28] Lewis, C.S. (2010). The Problem of Pain HarperCollins:New York, pp. 24-25.

[29] Durant, W. "Caesar and Christ". New York: Simon and Schuster, 1972.

[30] Chapman, J. "Doctors of the Church". The Catholic Encyclopedia, Vol. 5. New York: Robert Appleton Company, 1909.

[31] Anatolios, K. "Athanasius: The Coherence of His Thought." New York: Routledge, 1998.

[32] Wilken, RL. "A Learned Faith: Origen of Alexandria". The First Thousand Years: A Global History of Christianity. New Haven and London: Yale University Press. pp. 55-64, 2013.

[33] Audi, R. The Cambridge Dictionary of Philosophy. Cambridge University Press, 1999.

[34] Moore, E. (2005). Origen of Alexandria and St. Maximus the Confessor: An Analysis and Critical Evaluation of their Eschatological Doctrines. Boca Raton, Florida: Universal Publishers.

[35] Finn, R. "Origen and his ascetic legacy". Origen and his ascetic legacy, in: Asceticism in the Graeco-Roman World, Cambridge University Press. pp. 100-130, 2009. DOI:10.1017/CBO9780511609879.005

[36] McGuckin, JA. The Westminster Handbook to Origen. Louisville, Kentucky: Westminster John Knox Press, 2004

[37] Hilliard, CB. Intellectual Traditions of Pre-colonial Africa. McGrawHill College; 1st edition (September 1, 1997), 1998.

[38] Ames, C. "Roman Religion in the Vision of Tertullian." In A Companion to Roman Religion. Edited by Jörg Rüpke, 457-471, Oxford: Blackwell, 2007.

[39] Versluis, A. Magic and Mysticism: An Introduction to Western Esoteric Traditions. Rowman \& Littlefield Publishers, 2007.

[40] Ekonomou, AJ. Byzantine Rome and the Greek Popes: Eastern influences on Rome and the papacy from Gregory the Great to Zacharias, A.D. 590-752. Lexington Books, 2007.

[41] Osborn, EF. Tertullian, First Theologian of the West. Cambridge, UK: Cambridge University Press, 2003.

[42] Gonzáles, JL. "The Early Church to the Dawn of the Reformation". The Story of Christianity. 1. New York: HarperCollins Publishers. pp. 9193, 2010.

[43] Cornwell, H, Cornwell, J. Saints, Signs, and Symbols (3rd ed.). Harrisburg: Morehouse Publishing, 2009.

[44] White, C. Early Christian lives: life of Antony by Athanasius, life of Paul of Thebes by Jerome, life of Hilarion by Jerome, life of Malchus by Jerome, life of Martin of Tours by Sulpicius Severus, life of Benedict by Gregory the Great, (trans.), London: Penguin Books, 1998.
[45] Nthamburi, Z. Toward Indigenization of Christianity in Africa: A Missiological Task. International Bulletin of Missionary Research, 13(3), 112-118, 1989. [Available online at https://doi.org/10.1177/239693938901300304].

[46] Anatolios, K. Retrieving Nicaea: The Development and Meaning of Trinitarian Doctrine, Grand Rapids, Michigan: Baker Academic, 2011.

[47] Baur, J. 2000 years of Christianity in Africa. Nairobi: Pauline Publications Africa, 1994.

[48] Frend, WHC. The Donatist Church: A Movement of Protest in Roman North Africa. Reprint, Oxford: Clarendon Press, 1952.

[49] Brisson, JP. Autonomisme et christianisme dans l'Afrique romaine. Paris, 1958.

[50] Isichei, E. A history of Christianity in Africa: from antiquity to the present. Grand Rapids: Eerdmans Publishing Company, 1995.

[51] Speel, C. The Disappearance of Christianity from North Africa in the Wake of the Rise of Islam. Church History, 29(4), 379-397, 1960 doi: $10.2307 / 3161925$

[52] Hanciles, J.J. (2019). The Oxford History of Protestant Dissenting Traditions, Volume IV: The Twentieth Century: Traditions in a Global Context- Print publication date: 2019 Published to Oxford Scholarship Online: April 2019 DOI: 10.1093/oso/9780199684045.001.0001

[53] Wilhite, DE. Ancient African Christianity: An Introduction to a Unique Context and Tradition, Routledge, 1st edition, 2017.

[54] Shillington, K. History of Africa, New York: St. Martin's Press, 1995a

[55] Ravenstein, EG. Bartolomeu Dias. William Brooks Greenlee, Pero Vaz de Caminha. England: Viartis, 2010.

[56] Crowley, R. Conquerors: How Portugal Forged the First Global Empire (First ed.). New York: Random House, 2015.

[57] Nicolaides, A. Early Portuguese imperialism: Using the Jesuits in the Mutapa Empire of Zimbabwe, International Journal of Peace and Development Studies, 2(4), 132-137, 2011.

[58] Smith, AK. "The Indian Ocean zone", in D. Birmingham and P. M Martin (eds.) History of Central Africa, Vol. 1, Longman: London, pp 205-244, 1983.

[59] Shillington, K. West African Christianity: The Religious Impact Macmillan International Higher Education, January 1995b.

[60] Luis Froes,161 Froes, L.G. (1561). India, 15 December 1561, (DPMAC), VIII, Lisbon, 1972, pp. 37- 43.

[61] Sanneh, L. West African Christianity: The Religious Impact. Orbis Books: New York, 2015

[62] Masondo, S. "Ironies of Christian Presence in Southern Africa." Journal for the Study of Religion, 31(2), 2018.

[63] Keefer, KHB. "The First Missionaries of the Church Missionary Society in Sierra Leone, 1804-1816: A Biographical Approach.' History in Africa, 44, 1-37, 2017. DOI: 10.1017/hia.2017.5

[64] BBC World Service. (n.d.). The Story of Africa- Christianity: 19th Century White Missionaries [Online at https://www.bbc.co.uk/worldservice/africa/features/storyofafrica/8cha pter4.shtml]

[65] Onyinah, O. "African Christianity in the twenty-first century." World \& World, 27(3), 305-314, 2007

[66] Koukousas, V. The Representation of the Patriarchate of Alexandria at Ferrara-Florence and the Fight against Proselytization in the Provinces from the 15th to 18th century: Investigation on the Basis of the Sources, Ekklesiastikos Pharos, 94, 260-289, 2012.

[67] Hayes, S. "Orthodox mission in tropical Africa." Missionalia, 24(3), 383-398, 1996.

[68] Gray, R. Black Christians and white missionaries. New Haven: Yale University Press, 1990.

[69] Shillington, K. (1995a). History of Africa, New York: St. Martin's Press.

[70] Kohnert, D. "Magic and witchcraft: Implications for Democratization and poverty-alleviating aid in Africa." World Development, 24(8), Elsevier: Amsterdam, pp. 1347-1355, 1996 http://dx.doi.org/10.1016/0305-750X(96)00045-9

[71] Mujere, J. "African intermediaries: African evangelists, the Dutch Reformed Church, and the Evangelisation of the southern Shona in the late 19th century." Studia Historiae Ecclesiasticae, 39(2), 133-148, 2013.

[72] Urch, GE. "Education and colonialism in Kenya." History of Education Quarterly, 11(3), 249-264.

[73] Balcomb, AO. "Evangelicalism in Africa. What it is and what it does." Missionalia, 44(2), 117-128 2016. https://dx.doi.org/10.7832/44-2 142.

[74] Woodberry, RD, Shah, TS. "The pioneering Protestants." Journal of Democracy, 15, 47-61, 2004.

[75] Zurlo, G.A. (2020). African Christianity, Gordon Conwell Theological Seminary, [Available online https://www.gordonconwell.edu/blog/african-christianity101/?_cf_chl_jschl_tk]. 
[76] Van der Merwe, D. "From Christianising Africa to Africanising Christianity: Some hermeneutical principles." Stellenbosch Theological Journal, 2(2), 559-587, 2016 https://dx.doi.org/10.17570/stj.2016.v2n2.a25.

[77] Derrick Mashau, T. "Ministering effectively in the context of Pentecostalism in Africa: A reformed missional reflection." In die Skriflig, 47(1), 10-17, 2013.

[78] Asamoah-Gyadu, JK. "Hearing in your own tongues the wonderful works of God: Pentecost, ecumenism and renewal in African Christianity." Missionalia, 35(3), 128-145, 2007.

[79] Phiri, I, Maxwell, J. "Africa's rapid embrace of prosperity Pentecostalism provokes concern and hope." Christianity Today, July, 51(7), 2007.

[80] Mbefo, LN. Towards a mature African Christianity, SNAAP Press Ltd, 1989.

[81] Mkandawire, AC. (2009). David Livingstone's medical dimension in Malawi and how it is connected to his vision 150 years after his death. The Society of Malawi Journal 62(1), 62-65.

[82] Yong, A. Mission after Pentecost: The Witness of the Spirit from Genesis to Revelation, Grand Rapids: Baker Academic, 2019.

[83] Mbiti, JS. Introduction to African religion, Heinemann: London, 1975.

[84] Baëta, CG. (Ed.). Christianity in Tropical Africa, London: Oxford University Press, for the International African Institute, 1968.

[85] Ranger, TO, Weller, J. (Eds.) Themes in the Christian History of Central Africa, Heinemann Educational Books: London, 1975.

[86] Magesa, L. (2002). African religion: The moral traditions of abundant life, Orbis Books, Maryknoll.

[87] Sihvola J. Aristotle on the Individuality of Self. In: Remes P., Sihvola J. (eds) Ancient Philosophy of the Self. The New Synthese Historical Library, Texts and Studies in the History of Philosophy, vol 64. Springer: Dordrecht, 2008. https://doi.org/10.1007/978-1-4020-85963_6.

[88] Wernhart, KR. "Ethnische religionen [Ethnic religions]", in J. Figl (ed.), Handbuch Religionswissenschaft: Religionen und ihre zentrale Themen, Tyrolia-Verlag: Innsbruck, 2003.

[89] Rakotsoane, F. Transcendence in African Traditional Religions. Paper presented at the 16th Conference of the South African Science and Religion Forum (SASRF) of the Research Institute for Theology and Religion, University of South Africa, Pretoria, 2-3 September 2010. [Available online: http://uir.unisa.ac.za/handle/10500/4282?].

[90] Carmody, DL. The oldest God: Archaic religion yesterday \& today, Abingdon: Nashville, 1981

[91] Marwick, M. (Ed.) Witchcraft and Sorcery. Selected Readings, Harmondsworth: Penguin, 264-279, 1975.

[92] Kingsley, M. West African Studies. London: MacMillan, 1901.

[93] Mesaki, S. "The Evolution and Essence of Witchcraft in Pre-Colonial African Societies." Transafrican Journal of History, 24: 162-177, 1995.

[94] Gechiko-Nyabwari, BG, Nkonge-Kagema, D. "The Impact of Magic and Witchcraft in the Social, Economic, Political and Spiritual Life of African Communities." International Journal of Humanities, Social Sciences and Education, 1(5), 9-18, 2014

[95] Mair, L. Anthropology and Social Change. London: Athlone Press, 1969.

[96] Mazrui, AA. "Religion and Political Culture in Africa." Journal of the American Academy of Religion, 53(4), 817-839, 1985.

[97] Magesa, L. African religion: The moral traditions of abundant life, Orbis Books, Maryknoll,2002.

[98] George, S, Harold, G. "Motus Dei (The Move of God): A Theology and Missiology for a Moving World." Pharos Journal of Theology, 102, 2021.

[99] Lange, D. The dying and the rising God in the New Year Festival of Ife, in: Lange, Ancient Kingdoms of West Africa, Dettelbach, 343 376, 2004.

[100]Idowu, B. Olódùmarè: God in Yorùbá Belief. Ikeja, Nigeria: Longman, 1982.

[101]Hiebert, PG. Transforming Worldviews: An Anthropological Understanding of How People Change. Grand Rapids: Baker Academics, 2008.

[102]Ephirim-Donkor, A. African Religion Defined: A Systematic Study of Ancestor Worship among the Akan. University Press of America, 2012.

[103] Shorter, A. Prayer in the Religious Traditions of Africa. Oxford University Press: Nairobi, 1975.

[104]Uka, E.M. (Ed.), Readings in African Traditional Religion Structure, Meaning, Relevance, Future, Peter Lang: New York, 1991.
[105]Turaki, Y. (1999). Christianity and African gods, Potchefstroomse Universiteit vir Christelike Hoër Onderwys (now known as North-West University), Potchefstroom.

[106] Sundermeier, T. Nur gemeinsam können wir leben: Das Menschenbild schwarzafrikanischer Religionen [Only together can we live: The humanity of Black African religions], Gütersloher Verlagshaus Gerd Mohn: Gütersloh, 1990.

[107]Beyers, J. "What is religion? An African understanding." HTS Teologiese Studies/Theological Studies, 66(1), 2010. DOI: 10.4102/hts.v66i1.341

[108]Ndulor, CU. Osu caste system and Christianity in Igboland (Doctoral dissertation seminar paper). Department of Religion and Cultural Studies, University of Nigeria: Nsukka, 2014

[109]Okeke, CO, Ibenwa, CN, Okeke, GT. Conflicts Between African Traditional Religion and Christianity in Eastern Nigeria: The Igbo Example. SAGE Open, 2017 https://doi.org/10.1177/2158244017709322.

[110] Offiong, D. Witchcraft, sorcery, magic and social order among the Ibibio of Nigeria, Enugu: Fourth Dimension Publishers, 1991.

[111]Viegas, F. Panorama das Religiões em Angola Independente (19752008), Ministério da Cultura/Instituto Nacional para os Assuntos Religiosos: Luanda, 2008.

[112] Ademiluka, Solomon O. "A Study of Malachi 3:8-12 in Relation to Tithing in some Churches in Nigeria." Old Testament Essays, 33(2), 285-305, 2020. https://dx.doi.org/10.17159/2312-3621/2020/v33n2a8

[113]Nicolaides, A. (2016). "Spirituality and Cultural Diversity: Serving the Hospitality Industry Workplace", African Journal of Hospitality, Tourism and Leisure, 5(1):1-17

[114]Berkhof, L. Systematic Theology, London: Banner of Truth, 572, 1949.

[115] Moila, M. (1991). The African version of Christianity, Journal of Black Theology in South Africa, 5(1), 33-39.

[116] Mangany, JS, Buitendag, J. “A critical analysis on African Traditional Religion and the Trinity." HTS Theological Studies, 69(1), 2013.

[117]Maluleke, TS. "Half a century of African Christian Theologies." Journal of Theology for Southern Africa, 99, 4-23, 1997.

[118]Idowu, B. Towards an Indigenous Church, London, Oxford University Press, 1995.

[119] Mulago, V. La religion traditionelle des Bantu et leur vision du monde, Kinshasa: Faculte de theologie catholique, 1980.

[120]Masoga, MA. "Gabriel Molehe Setiloane: His intellectual legacy." Studia Historiae Ecclesiasticae, 40(Suppl.1), 33-52. Retrieved June 23, 2021, Available online at: http://www.scielo.org.za/scielo.php?script=sci_arttext\&pid=S101704992014000200004\&lng=en\&tlng=en.

[121]Masoga, MA. A critical dialogue with Gabriel Molehe Setiloane: The unfinished business on the African divinity question, Studia Historiae Ecclesiasticae, 38(Suppl. 1), 1-13. Retrieved June 23, 2021, from Available online http://www.scielo.org.za/scielo.php?script=sci_arttext\&pid=S1017 04992012000300003\&lng=en\&tlng=en.

[122] Masoga, MA, Mathye, MM. "Simon Maimela in the Chamber of African Theology." A Methodological Challenge, Studia Historiae Ecclesiasticae, 36, 67-80, 2010.

[123] Masango, MJS. "African spirituality that shapes the concept of Ubuntu." Verbum et Ecclesia, 27(3), 930-943, 2006.

[124]Shorter, A. (2015). Inculturation of African Traditional Religious Values in Christianity: How Far? Available Online at: http://www afrikaworld.net/afrel/shorter. htm.

[125] Martey, E. African Theology: Inculturation and Liberation. Maryknoll, N.Y.: Orbis Books, 1993.

[126] Obijole, OO. "The church and the gospel message in the African cultural context." Ogbomoso Journal of Theology, 171(1), 99-116, 2012.

[127]Freire, P. Pedagogy of Freedom: Ethics, Democracy and Civic Courage. Lanham, Rowman \& Littlefield Publishers, 1998.

[128]Mbiti, J. S. (1971). New Testament Eschatology in an African Background: A Study of the Encounter between New Testament Theology and African Traditional Concepts. London: Oxford University Press.

[129]Idowu, B. (1995). Towards An Indigenous Church, London, Oxford University Press.

[130] Moltmann, J. The Crucified God: The Cross of Christ as the foundation and criticism of Christian theology. New York: Harper \& Row, 1974

[131]Shorter, AWF. African culture and the Christian church: An introduction to social and pastoral anthropology, Geoffrey Chapman Publishers: London, 1973. 